\title{
Potential Role of Venular Amyloid in Alzheimer's Disease Pathogenesis
}

\author{
Christopher D. Morrone ${ }^{1, *,+}$, Jossana Bishay ${ }^{1,2,+}$ and JoAnne McLaurin ${ }^{1,2}$ \\ 1 Sunnybrook Research Institute, Biological Sciences, 2075 Bayview Ave, Toronto, ON M4N 3M5, Canada; \\ jossana.bishay@mail.utoronto.ca (J.B.); jmclaurin@sri.utoronto.ca (J.M.) \\ 2 Faculty of Medicine, Department of Laboratory Medicine and Pathobiology, University of Toronto, \\ 1 King's College Cir, Toronto, ON M5S 1A8, Canada \\ * Correspondence: morrone.cdm@gmail.com; Tel.: +1-416-480-6100 (ext. 5034) \\ + These authors contribute equally to this work.
}

Received: 8 February 2020; Accepted: 12 March 2020; Published: 14 March 2020

check for updates

\begin{abstract}
Insurmountable evidence has demonstrated a strong association between Alzheimer's disease (AD) and cerebral amyloid angiopathy (CAA), along with various other cerebrovascular diseases. One form of CAA, which is the accumulation of amyloid-beta peptides $(A \beta)$ along cerebral vessel walls, impairs perivascular drainage pathways and contributes to cerebrovascular dysfunction in AD. To date, CAA research has been primarily focused on arterial $\mathrm{A} \beta$, while the accumulation of $A \beta$ in veins and venules were to a lesser extent. In this review, we describe preclinical models and clinical studies supporting the presence of venular amyloid and potential downstream pathological mechanisms that affect the cerebrovasculature in AD. Venous collagenosis, impaired cerebrovascular pulsatility, and enlarged perivascular spaces are exacerbated by venular amyloid and increase $A \beta$ deposition, potentially through impaired perivascular clearance. Gaining a comprehensive understanding of the mechanisms involved in venular $A \beta$ deposition and associated pathologies will give insight to how $\mathrm{CAA}$ contributes to $\mathrm{AD}$ and its association with $\mathrm{AD}$-related cerebrovascular disease. Lastly, we suggest that special consideration should be made to develop A $\beta$-targeted therapeutics that remove vascular amyloid and address cerebrovascular dysfunction in AD.
\end{abstract}

Keywords: venular amyloid; $A \beta$; vein/venule; Alzheimer's disease; cerebral amyloid angiopathy; venous collagenosis; perivascular clearance; TgF344-AD rat model

\section{Introduction}

\subsection{Alzheimer's Disease}

Cognitive decline, memory impairment, and loss of activities of daily living are a few of the debilitating clinical symptoms of Alzheimer's disease (AD), the most common form of dementia [1,2]. There exists two neuropathological hallmarks characteristic of disease; extracellular deposition of $\mathrm{A} \beta$ peptide into amyloid plaques and accumulation of hyperphosphorylated tau into neurofibrillary tangles within neurons [3,4]. Familial AD results from mutations in one of either the amyloid precursor protein (APP) or presenilin-1/-2 genes (PS1/PS2) [5,6]. Overall, mutations in these genes cause an overproduction of $A \beta$, specifically $A \beta 40 / 42$, found in parenchymal $A \beta$ plaques [1,4]. Familial $A D$ develops earlier than late onset $\mathrm{AD}$ ( $<65$ years), has a more severe clinical course, and is quite rare, accounting for approximately $1-6 \%$ of all $\mathrm{AD}$ cases [7]. In contrast, late onset $\mathrm{AD}$ is the most common form of $\mathrm{AD}$ with onset $>65$ years, and a major focus in understanding the possible risk factors that contribute to disease $[4,8]$.

$\mathrm{A} \beta$ aggregates in the form of amyloid plaques within the brain parenchyma, typically spreading through the cortex and eventually to the hippocampus [1,9], leading to synaptic loss, neuronal cell death, 
and brain atrophy $[10,11]$. This neurodegenerative process contributes to the dementia that is seen in $A D$ patients [12-14]. Although $A \beta$ aggregation is one of the major drivers of $A D$, research has demonstrated cerebrovascular dysfunction to be an important risk factor in late onset $A D$, occurring earlier than cognitive decline and prior to $A \beta$ deposition [15-18]. Cerebrovascular morphological alterations, blood-brain barrier (BBB) dysfunction, reduced cerebral blood flow, and decreased vascular reactivity are involved in $\mathrm{AD}[10,17,18]$. Another pathological hallmark of $\mathrm{AD}$ that contributes to vascular dysregulation is the presence of $A \beta$ deposition in the walls of cerebral vessels, known as cerebral amyloid angiopathy (CAA) [2]. The consequences of CAA, in combination with cerebrovascular dysfunction, further contributes to dementia $[1,10]$. Therefore, it is of significant importance to understand the role of the vasculature in $\mathrm{AD}$, as well as elucidate how CAA contributes to disease progression.

\subsection{Cerebral Amyloid Angiopathy}

CAA is one of the most common forms of small vessel disease, defined as the pathological alterations in the small cerebral blood vessels due to accumulation and deposition of a wide variety of amyloid proteins $[8,19]$. Amyloid proteins are native proteins that undergo a conformational abnormality, causing them to become highly insoluble and prone to aggregation $[8,19,20]$. In hereditary $\mathrm{CAA}$, there are numerous genetic mutations that give rise to the deposition of several amyloid proteins, leading to severe clinical symptoms $[19,20]$. The APP Dutch mutation, of the single amino acid substitution at residue 22 of the $\mathrm{A} \beta$ protein, is a genetic hallmark of the autosomal dominant condition, hereditary cerebral hemorrhage with amyloidosis (HCHWA)-Dutch type, resulting in severe CAA composing of both wild-type $A \beta$ and the Dutch-type variant $[19,20]$. HCHWA-Dutch is a fatal disease characteristic of cerebral hemorrhages, stroke, and vascular dementia [19-21]. Other genetic variants of the APP gene include Swedish (KM670/671NL), Flemish (A692G), Iowa (D694N), and French (V715M) mutations, and also result in a similar clinical presentation as HCHWA-Dutch [8,20,22]. Additionally, mutations in the PS1 and PS2 genes contribute to severe CAA [19]. Other genetic modifications include mutations in the cystatin $C$, transthyretin, and gelsolin genes, resulting in vascular amyloid deposition leading to HCHWA-Icelandic Type, familial amyloid polyneuropathy/meningo-vascular amyloidosis, and familial amyloidosis Finnish type, respectively $[19,20]$. Hereditary causes of CAA are reviewed in more detail elsewhere [20]. Overall, hereditary CAA is rare, more severe in pathology, and commonly has an earlier age of onset, in comparison to sporadic CAA $[8,19,23,24]$.

In 1938, Scholz was the first to describe CAA in the brains of the elderly [25] and it was not until 1954 that CAA was shown to be distinct from AD, as it was not associated with parenchymal plaques [26]. However, it is important to note the high comorbidities between these disorders, with prevalence of CAA in $80-90 \%$ of patients with AD [2,8,19,27]. Moreover, just as the apolipoprotein $E(\mathrm{ApoE})$ gene contributes to the disease progression of $\mathrm{AD}, \mathrm{ApoE}$ is also a genetic risk factor for sporadic CAA and cerebrovascular disease [10]. In particular, ApoE $\varepsilon 2$ and $\varepsilon 4$ alleles are known to be associated with $C A A$, with extensive vascular $A \beta$ deposition shown in CAA patients with either allele; whereas $\varepsilon 2$ has additionally demonstrated an increased risk of cerebral hemorrhages, despite its known protective effects in $\mathrm{AD}[8,9,22]$.

CAA involves the aggregation and deposition of both $A \beta 40$ and $A \beta 42$ peptides $[8,19,23,24]$. $A \beta 40$ is the predominant isoform in vascular amyloid, the inverse of which is observed in parenchymal plaques; however, evidence suggests that $\mathrm{A} \beta 42$ is necessary to initiate CAA deposition [22,28]. Interestingly, the $A \beta 40: 42$ ratio in capillaries resembles that in parenchymal plaques and not arterial or venular CAA $[22,29]$. This suggests that soluble $A \beta 42$ acts as an initial seed of vascular $A \beta$, but with disease progression $A \beta 42$ deposits into parenchymal plaques. Perivascular clearance of primarily smaller soluble $A \beta$ peptides (i.e. $A \beta 40$ ) facilitates their deposition along arteries and veins. In support of this, $A \beta$ peptides of 36 to 41 amino acids in length preferentially deposit in CAA, whereas $A \beta$ peptides of 42 and 43 amino acids preferentially deposit in plaques (reviewed in [22]).

It has been of recent interest to understand CAA and its involvement in cerebrovascular diseases, as it is one of the major causes of intracerebral hemorrhages [8,21]. CAA manifests itself in several 
clinical features such as stroke, leukoaraiosos (i.e. white matter hyperintensities), ischemia, and dementia [30-33]. Vascular A $\beta$ deposition compromises the cerebrovasculature by weakening blood vessels and increasing vascular resistance, predisposing these vessels to microinfarctions that cause ischemia or hemorrhages [32,34]. Subsequently, vessel rupture and microbleeds occur in cases of CAA regardless of whether patients have AD [22,35]. Since vascular amyloid (i.e. CAA) is involved in most $\mathrm{AD}$ cases, it is of great import to understand the role of CAA to gain insight on how vascular amyloid affects the neurovasculature, contributing to the debilitating clinical symptoms in AD patients.

\section{Impaired Perivascular Clearance of $A \beta$}

There is currently little to no solid evidence of overproduction of $A \beta$ in late onset $A D$, suggesting that the accumulation of $A \beta$ is due to impairment of clearance $[4,8,36]$. There are several mechanisms involved in the elimination of small solutes, such as $A \beta$, from the brain. Of these, the perivascular drainage pathway has a pathological role in $\operatorname{AD}[24,37,38]$. The perivascular drainage pathway is the movement of small solutes along the interstitial fluid (ISF) and into the spaces that surround cerebral microvessels, which are called perivascular spaces or Virchow-Robin spaces [31]. Currently, there are two perivascular drainage pathways that have been proposed in the literature: the intramural periarterial drainage pathway and the glymphatic clearance pathway [39,40].

The intramural periarterial drainage pathway, involves the bulk flow of ISF into the basement membranes of capillaries and arteries that surround smooth muscle cells $[4,39,41]$. In CAA, amyloid usually deposits along smooth muscle cells of the tunica media and basement membranes of the tunica adventitia of artery walls, which is the site of the periarterial drainage [24,39]. This suggests that poor clearance of this drainage pathway contributes to vascular $A \beta$ deposition and CAA [34,41,42]. In addition, $A p o E \varepsilon 4$ has also been associated with reduced perivascular drainage of $A \beta$ along the periarterial pathway [43]. The glymphatic clearance pathway involves the periarterial influx of cerebral spinal fluid (CSF) entering the brain, which combines with ISF and moves along the venous perivascular spaces of large cerebral veins [40,42]. Aquaporin 4 (AQP4) water channels located at the endfeet of perivascular astrocytes largely support the bulk flow of CSF-ISF by facilitating influx of CSF through the periarterial spaces, while promoting clearance of ISF through the perivenous pathway $[39,40,42]$. Soluble $A \beta$ is one of the solutes that drains along the glymphatic clearance pathway [42] and recent reports demonstrate this perivenous drainage to be impaired in $\mathrm{AD}[38,39]$. We propose that no drainage pathway within the brain acts in isolation and thus, dysfunction of either the periarterial or the perivenous pathways would shift the clearance to the alternate pathway and strain existing mechanisms potentially leading to increased deposition in that blood vessel.

Although both arteries and veins are involved in $A \beta$ drainage, there has been controversy regarding the distribution of $A \beta$ within different vessel walls. Pathological analyses demonstrated that CAA leads to amyloid deposition along arteries and capillaries, with minimal involvement of veins in the AD pathology [24,34]. Human pathological data have been questioned in regards to the lack of consistent methods used to distinguish between arterioles and venules. The reliance on the ratio between the vessel wall thickness to lumen diameter [44] may be flawed as this ratio can be altered due to brain tissue processing [44]. Distinguishing between arterioles and venules is of particular import to correctly identify the type of vessels involved in cerebrovascular pathologies. Accordingly, the pathophysiology of the venous system should not be ignored when studying AD.

\section{Evidence of $A \beta$ in Veins and Venules}

The venous system of the cerebrovasculature has had scarce attention in regards to understanding the mechanisms involved in CAA, and, in association, AD [33]. Recently, there has been increased importance in studying the pathology of veins and venules, not only in the context of AD or CAA, but also in small vessel disease and dementia overall $[30,45,46]$. Venous pathology has been shown to contribute to vascular dysfunction in $\mathrm{AD}$, resulting in white matter hyperintensities and microinfarcts, and potentially induction of ischemia $[30,45-48]$. However, more research is necessary to understand 
the role of veins and venules in AD and CAA. One controversial pathology of the venous system is the presence of venular amyloid, the deposition of $A \beta$ within veins and venules. As such, we discuss evidence for the presence of amyloid in veins and venules, suggesting that all vessels play a role in disease progression [27,49-51]. In addition, numerous reports demonstrate a suite of mechanisms that involve a pathological role for veins in CAA and $\mathrm{AD}[27,30,47,50-52]$. This section outlines the evidence for venular amyloid in both animal models and clinical cases, in the context of AD and CAA.

\subsection{Preclinical Models}

Currently, in vivo animal studies have observed venular amyloid. The APP+PS1 rat model, that shows extensive $\mathrm{CAA}, \mathrm{A} \beta$ plaque formation, and behavioural alterations, demonstrated $\mathrm{A} \beta$ deposits in leptomeningeal and cortical arteries, cortical capillaries, as well as severe deposition in the leptomeningeal and cortical veins using immunohistochemical analyses [53]. In addition, there were significant alterations in the veins including enlarged cortical veins and perivascular spaces, and stenosis of collagen, tau, and $A \beta$ [53]. These pathological features have also been identified clinically in venous insufficiency and vasogenic edema, typically depicted as hyperintensities in magnetic resonance imaging (MRI) [30,31,47,52,54,55].

Further studies identify A $\beta$ in veins of TgF344-AD rats, that overexpress human Swedish APP and PS1 with exon 9 excised [56]. TgF344-AD rats recapitulate AD progression in humans including age-dependent cerebral amyloidosis, CAA, tau pathology, neuronal loss, and cognitive dysfunction [56]. In studying early neurovascular dysfunction, Joo and colleagues demonstrated that vascular $A \beta$ deposition was not exclusive to arterioles and can be found in venules to a lesser degree, at 9 months of age [18]. Moreover, TgF3444-AD rats have a 51\% decrease in vascular reactivity in venules in response to hypercapnic conditions [18]. Here we show amyloid deposition in the veins of TgF344-AD rat models at 16 months of age (Figure 1). The topography of these amyloid deposits are quite distinct from deposition in arteries (Figure 1a); where venous $A \beta$ deposits appear more globular and have a patchy distribution (Figure $1 b$ ), whereas arteriolar $A \beta$ possessed a 'double-barreling' morphology, forming striped rings, which is in correspondence with previous literature $[19,27,57]$. Since Joo and colleagues showed significantly less amyloid deposition in veins and venules relative to arteries and arterioles [18], we propose an age-dependent association between arterial (Figure 1a) and venular amyloid (Figure 1b). However, further research is necessary to understand the interplay between these amyloid deposits as age and AD progresses.

\section{a) Artery}

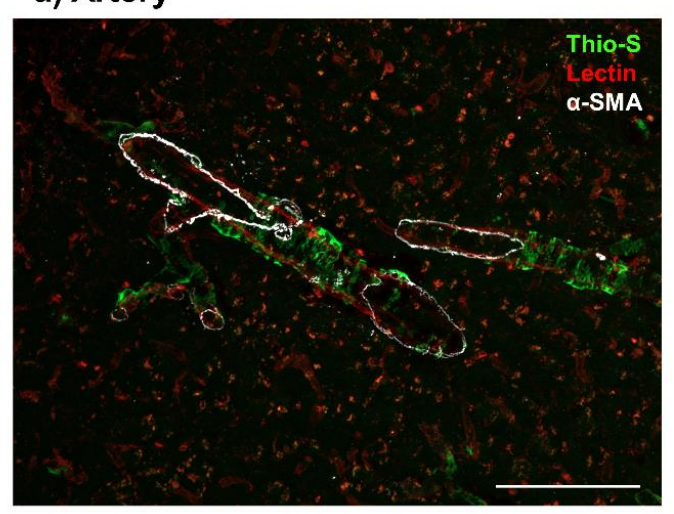

\section{b) Vein}

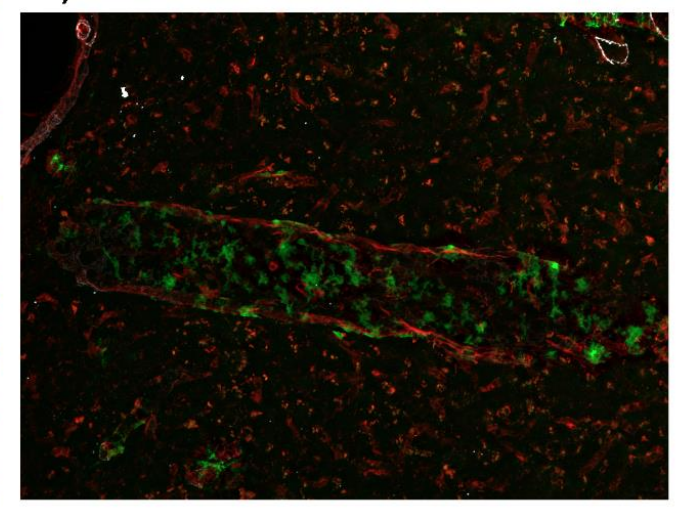

Figure 1. Presence of venular amyloid in 16-month old TgF344-AD rats. Immunofluorescence imaging of vascular amyloid deposition, stained by Thioflavin S (Thio-S, green), in cortical penetrating vessels (Lectin, red). Amyloid beta peptide (A $\beta$ ) deposits present a 'double-barreling' morphology, forming cyclical rings surrounding the arteries (a). Venular $A \beta$ is present as smaller, globular deposits along the veins (b). Arteries were distinguished from veins by presence of alpha smooth muscle actin ( $\alpha$-SMA, white). Scale bar $=100 \mu \mathrm{m}$. 
Mouse models have demonstrated impairment and/or suppression of both the periarterial drainage pathway and the glymphatic clearance pathway in $\mathrm{AD}[37,38,58]$. Intracerebral injections of a dextran tracer were performed in 3-, 7-, and 22-month old Tg2576 mice, a model of AD overexpressing the human Swedish APP mutation [37]. Hawkes and colleagues demonstrated that a 3-kDa dextran almost exclusively drains along the basement membranes of capillaries and arteries in non-transgenic mice, with little to no drainage in veins $[37,41]$. In agreement, an AD mouse model with the overexpression of the London mutation within the human $A P P$ gene exhibited significant $A \beta$ deposition along the walls of arteries but sparse deposition along veins [59]. However, most striking in the Tg2576 AD mice, not only were capillaries and arteries positive for dextran in all ages, but dextran-positive staining along veins was detected at 22 months of age [37]. These results suggest that $A \beta$ deposition in arteries and capillaries can exacerbate periarterial drainage altering the nascent clearance route of solutes from the brain [37]. An alternate explanation for the presence of dextran, and potentially $A \beta$, along veins may be impaired glymphatic drainage with aging $[38,58]$.

One report demonstrated venular amyloid in APP/PS1/Cx3cr1 mice presenting as small, globular $A \beta$ aggregates in veins at 5 months of age and at 9 months of age, along with the presence of the ring-like $A \beta$ deposition in arteries [27]. Michaud and colleagues proposed that the $A \beta$ deposits in veins precede arterial $A \beta$ deposition [27], which is contrary to previous findings [18,37,53,59]. In addition, Michaud and colleagues demonstrated preferential adherence of monocytes to surrounding A $\beta$-laden veins, but not arteries, and that these monocytes internalize venular amyloid for removal into the bloodstream [27]. This work proposes underlying mechanisms that contribute specifically to clearance of $A \beta$ via veins and venules and further raises the question about the knowledge gap regarding the relationship between $A \beta$ deposition in arteries/ arterioles versus veins/venules.

Preclinical studies showed venular amyloid in multiple models of AD but was observed to a lesser extent compared to arterial CAA. We previously proposed two models that may explain the lower presence of amyloid in veins and venules, despite the important role of veins in the glymphatic drainage system [39]. The first is that the lack of the highly organized smooth muscles cells in veins and venules result in less substrates for $A \beta$ deposition and, secondly, monocytes that exclusively adhere to veins might clear $A \beta$ as it deposits along the venular walls $[4,27,39]$. In addition to the preclinical models discussed above, there are reports that do not distinguish between arteries and veins [60-64], or exclusively report of CAA in arteries $[65,66]$. Therefore, the present findings in this section address the need for characterization of all cerebral vessels to accurately gain a comprehensive understanding of both arterial and venous CAA.

\subsection{Clinical Evidence}

Cases of venular amyloid deposition have been reported as early as the 1980s, where 45 patients were studied to determine the relationship between vascular amyloid and amyloid plaques [49]. The proportion of $A \beta$ deposition in each vessel was recorded according to a severity measurement, $0-4$, now termed as the Mountjoy scale $[49,50]$. Mountjoy and colleagues determined the presence of amyloid not only in arteries, but in veins of 21 patients, as depicted by Congo Red staining, with one case having severe amyloid deposition in veins [49].

Weller and colleagues also demonstrated $\mathrm{A} \beta$ deposition in veins, although to a lesser extent compared to arterial $\mathrm{A} \beta$ deposition [24,34]. In one case study, $17 \mathrm{AD}$ brains were examined to determine $A \beta$ deposition in accordance with perivascular drainage. The leptomeningeal vessels were stripped from the surface of the brain and were stained with Thioflavin $S$ to quantify amyloid deposition in 681 arteries and 352 veins. $A \beta$ deposition demonstrated a 5:1 distribution in arteries compared to veins, with approximately $4.5 \%$ of veins positive for amyloid [34]. In a clinical case study of AD, Weller and colleagues also observed $A \beta$ deposition in the walls of veins in the presence of severe CAA [24]. As very little $A \beta$ deposits were detected in these veins, Weller and colleagues considered these deposits as rare, and attributed the CAA pathology to impaired clearance of the periarterial drainage pathway [24]. 
Current disease models suggest that even when rare, venular $A \beta$ can impair glymphatic clearance, contribute to $\mathrm{A} \beta$ deposition, and exacerbate $\mathrm{CAA}$ and $\mathrm{AD}$ progression $[22,24,34,39,40,42]$.

In contrast, a neuropathological study of 69 human autopsy brains assessed the distribution of $A \beta$ deposition across different vessels and the association with pathological features such as CAA severity and AD-related A $\beta$ pathology [51]. Two types of CAA were identified; CAA Type 1 and CAA Type 2, which were associated with the presence and absence of capillary A $\beta$ deposition, respectively. An important observation in this study was that both CAA types showed A $\beta$ deposition in leptomeningeal and cortical veins, suggesting that CAA is not exclusive to arteries, but also in veins and differentially in capillaries [51].

A recent paper examined the potential venular involvement in intracerebral hemorrhages [50]. All 41 patients showed the presence of CAA, as demonstrated by both Congo red and anti-A $\beta(8-17)$ immunohistochemical staining. The severity of the vascular $A \beta$ deposition was determined by the Vonsattel scale and the proportion of $A \beta$ in each vessel was recorded based on the Mountjoy scale [49]. Of the 41 cases, 33 patients had $A \beta$ deposits in veins, 15 of which showed severe $C A A, 13$ showed moderate CAA, and the remaining 5 patients showed mild CAA [50]. In light of the involvement of moderate and severe CAA associated with venular amyloid deposition, these data support our hypothesis that dysfunction of either the periarterial or the perivenuous pathways would shift clearance to the alternate pathway and strain existing mechanisms potentially leading to increased deposition in that blood vessel.

Overall, venular amyloid has been understudied with respect to vascular mechanisms involved in AD. Despite this, the involvement of venous and venular pathology in cerebral microinfarction and other cerebrovascular diseases have indicated that veins and venules play a strong role in contributing to dementia $[30,46]$. Moreover, compromise in the functional role of the venous system could in part be a major factor in impairing solute clearance from the brain, leading to vascular $A \beta$ deposition $[16,30]$. Therefore, studies elucidating the relationship between pathology in veins and venules with $A \beta$ deposition is of high interest.

\section{Contribution of Venular Amyloid to Alzheimer's Disease (AD) Pathogenesis}

In this review so far, we have proposed that accumulation of $A \beta$ along the venous system occurs to a greater degree than previously thought. Venular amyloid is likely an integral part of AD pathogenesis, and similar to arterial amyloid, contributes to cerebrovascular dysfunction and failure of $A \beta$ clearance mechanisms (Figure 2). In this section, we will discuss how venous collagenosis, arterial and venular pulsation impairments, and enlargements in the perivascular space may contribute to the accumulation of venular amyloid, and vice versa (Figure 2). We propose that $A \beta$ deposition in the venular system acts in a positive feedback manner, similar to arterial CAA, to increase vascular A $\beta$ deposition from impaired ISF efflux, and impair the cerebrovascular network.

Microinfarcts and small vessel disease commonly occur in AD patients, impairing cognition and increasing risk for stroke [30,67]. Recently, blockage of a single venule in mice vastly impaired cerebrovascular structure and function $[46,68]$. Acute venular occlusion in the mouse cortex decreases blood flow, increases vessel diameter, impairs local neuronal function and neurovascular coupling, induces severe hypoxia, and can cause somatosensory behavioural deficits [69-71]. Interestingly, even though mice have $2-3 x$ more cortical penetrating venules than arterioles, the occlusion of a single venule had a profound impact, indicating the potentially compounding effect of venular amyloid [46,68,72]. Conversely, humans have less venules for every arteriole [46], suggesting a greater strain on each individual venule. Therefore, venular amyloid, with the associated collagenosis and vascular impairments in $\mathrm{AD}$, likely accelerates disease progression. 

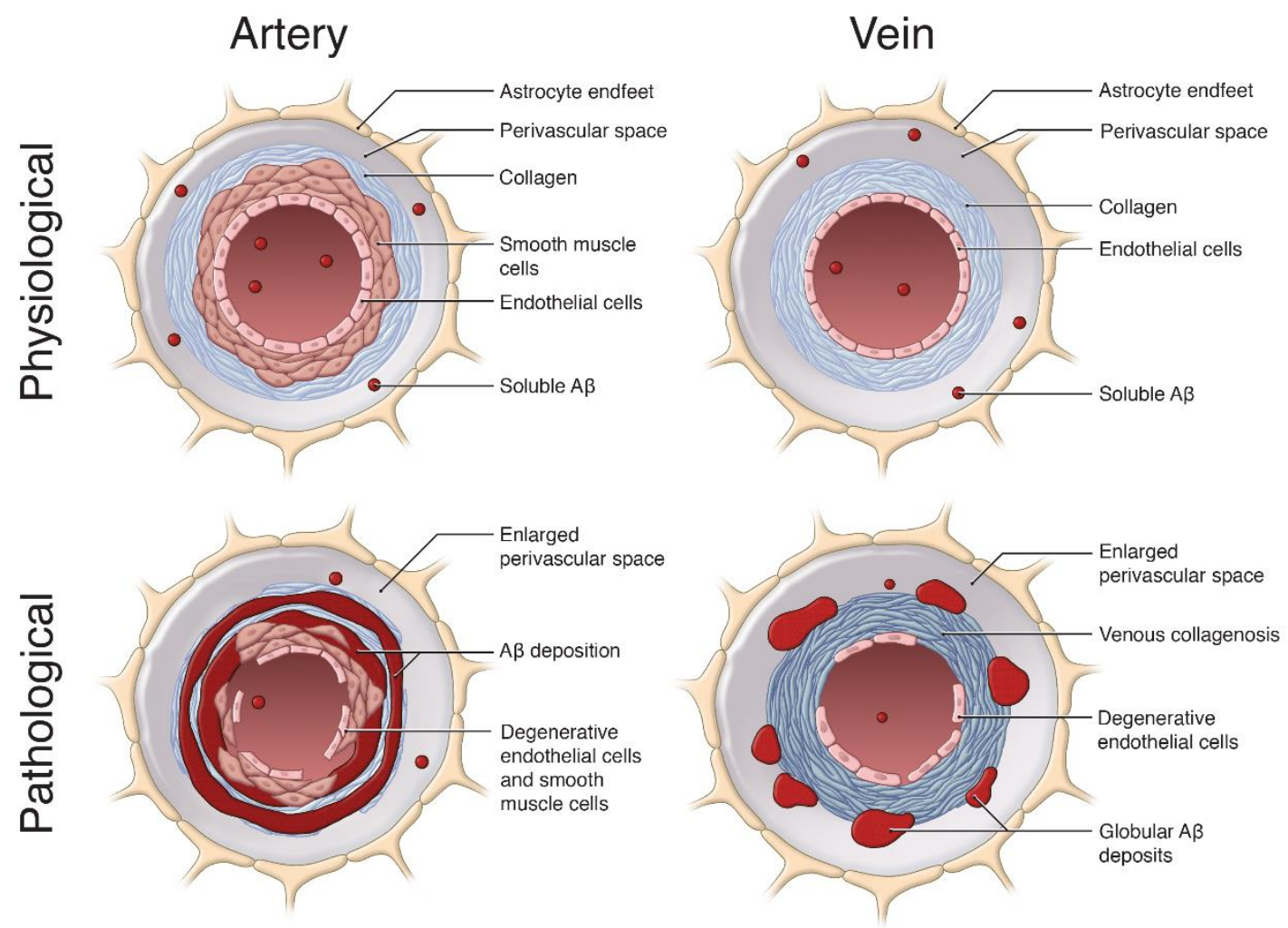

Figure 2. The pathological role of vascular $A \beta$ deposition on arteries and veins. This schematic summarizes the effects of $A \beta$ (red) accumulation on cerebral vessels, relative to physiological conditions. In physiological conditions, soluble $A \beta$ can be cleared from the brain into the vessel lumen and along the perivascular spaces of arteries and veins. In pathological arteries, $A \beta$ is deposited along the smooth muscle cells and basement membranes, forming a 'double-barreling' morphology surrounding the vessel, resulting in arterial smooth muscle and endothelial cell loss. In pathological veins, the $A \beta$ deposition is distinct, forming globular deposits in perivascular spaces. Venular $A \beta$ contributes to extensive venous collagenosis (dark blue) in the form of concentric rings along venular walls, significant enlargement of the perivascular space, and endothelial cell loss. These pathological features in arteries and veins exacerbate $A \beta$ accumulation, ultimately causing vascular and cognitive dysfunction in cases of cerebral amyloid angiopathy (CAA) and Alzheimer's disease (AD). Image not to scale. Image by Sherry Lai.

\subsection{Venous Collagenosis}

Venous collagenosis was first described in the mid 1990s as a non-inflammatory mural disease and collagenous thickening of the walls of periventricular venules and veins, associated with cases of leukoaraiosis and with aging [52,54]. Leukoariosis, also referred to as white matter hyperintensities, are MRI- and computed tomography-detectable markers of cerebrovascular dysfunction [30,54]. Moody and colleagues discovered collagenosis in the venules of $65 \%$ of people over 60 years of age histologically by excessive collagen accumulation and the replacement of venular mural cells with collagen. Vein and venule walls were thickened and exhibited concentric rings of collagen [52,54]: specifically, collagen 1 and 3 accumulated excessively in venular walls, indicative of hyalinization [16,73]. Collagenosis can occlude veins in individuals with leukoaraiosis, even in those who present with normal afferent vessels, and have profound effects on the cerebrovascular system, including impairment of perfusion pressure and blood flow $[46,52,54]$. Moody and colleagues originally observed collagenosis specifically on efferent vessels, not on capillaries or arterioles, which was most severe and abundant in the periventricular venular walls [52,54]. However, venous collagenosis was also detected in connected 
regions and in the cortex [54,73], suggesting that additional triggers such as amyloid could exacerbate collagenosis throughout the brain.

More recently, Keith and colleagues examined brains of $\mathrm{AD}$ patients for periventricular venous collagenosis and venous stenosis both of which positively correlated with and predicted the severity of white matter hyperintensities, a common AD-related cerebrovascular dysfunction $[47,74]$. Additionally, MRI images of periventricular white matter hyperintensities demonstrate the presence of venules within these lesions [30,55], suggesting an association with venous collagenosis. Keith and colleagues separated veins into small ( $<50 \mu \mathrm{m}$ diameter), medium $(50-150 \mu \mathrm{m}$ diameter), and large ( $>200$ $\mu \mathrm{m}$ diameter) vessels. Venous walls appeared thickened by the presence of collagen, and small and medium veins exhibited a greater collagen:lumen ratio, which positively correlated with severity of white matter hyperintensities. Large veins with prominent collagenosis were selected and percent stenosis was assessed by comparing the internal vessel diameter with the external (includes collagenous deposits) [47]. Overall, significant collagenosis and stenosis of the venous system, in particular in the deep medullary veins, occurred in AD patients [47]. In combination with the results described by Moody and colleagues, these data indicate that venous collagenosis is enhanced by both age and AD-related pathology, such as white matter hyperintensities, and can impair cerebrovascular structure, cause venous insufficiency, increase fluid leakage/vasogenic edema, and occlude blood flow $[30,46,47,52,54,55,75-77]$.

Evidence of venous collagenosis in AD preclinical models is limited to a single report in the $\mathrm{APP}+\mathrm{PS} 1$ rat model, which present with severe cortical and leptomeningeal venular A $\beta$ deposition [53]. Subsequently, these rats recapitulate collagenosis of the venous system as it was described in humans $[47,52]$. In APP+PS1 rats, venous collagenous leptomeningeal, cortical, hippocampal and cerebellar deposits and concentric stenosis associate with $A \beta$ deposition [53]. Enlargements in the area of vascular and perivascular spaces, as well as increased neuronal necrosis in the surrounding area demonstrate the extent of cerebrovascular impairments [53], which can contribute to functional deficits and to an increased $A \beta$ deposition from impaired clearance mechanisms [30,31,40,78].

The mechanisms by which venular amyloid deposition or venous collagenosis begin are not entirely understood. However, it is possible that glymphatic clearance of CSF-ISF along veins allows soluble $\mathrm{A} \beta$ to deposit in perivascular spaces and venular walls, similar to what is proposed for arterial CAA. This in turn will impair cerebrovascular function and exacerbate hyalinization of venules $[42,46,73,78]$. Interestingly, venous collagenous deposits in APP+PS1 rats were positive for the presence of A $\beta$ and tau in immunohistochemical staining [53], suggesting that the deposition of $A \beta$ may increase the deposition of collagen on venules, and vice versa. Additionally, oxidative stress and leukocyte adhesion have been implicated in the initiation of venous collagenosis, which are reviewed in [46]. Briefly, monocytes, which are known to adhere to $A \beta$-positive veins, can release reactive oxidative species that impair the venous system $[27,46,79]$. Finally, as a result of venular amyloid, collagen deposition will initiate structural and functional alterations in these vessels (Figure 2), specifically enlargements in the perivascular space, and alterations in pulsatility and blood flow, culminating in impaired perivenous $A \beta$ clearance which further exacerbates vascular $A \beta$ deposition and drives AD pathogenesis.

\subsection{Cerebrovascular Pulsatility}

Blood vessel wall rigidity and stiffness decrease blood flow through the cerebrovascular system. AD-related arterial CAA and venous collagenosis increase afferent vessel pulsatility and efferent vessel resistance, respectively $[30,34,54]$. Arterial A $\beta$ stiffens vessels and forms highly rigid vessel walls, thereby increasing pulsatility $[34,80,81]$. When this high-pressure blood flows into the AD venous system it is met with high resistance from amyloid and collagen deposits $[30,53,54]$, causing physical stress on venules [82]. Criswell and colleagues investigated arterioles and venules in aged canine brains and determined how regional differences in vessel structure impacts venular resistance and increased venous collagenosis [83]. Specifically, periventricular white matter venules demonstrated 
approximately half the intramural cells when compared to subcortical white matter venules, indicating a lower baseline vessel wall resistance. Because of lower resistance, there is an increased susceptibility to stress from arterial pulsatility in periventricular venules, offering a potential explanation for severe age-related collagenosis in these vessels $[52,83]$. In the context of AD-like pathology, it is possible that this effect is further exacerbated by arterial and venular $A \beta[34,51]$, since $A \beta 40$ is directly toxic to pericytes in vitro [84-86]. Loss of venular mural cells, which are primarily pericytes, has been well demonstrated in AD rodent models [18,45], and mural cell loss associates with cognitive decline in AD patients $[87,88]$.

Furthermore, cerebrovascular $A \beta$ directly correlates with impairments in vessel pulsation and resistance in $\mathrm{AD}$ [81]. Utilizing transcranial color-coded duplex sonography, Ortner and colleagues determined that high pulsatility and resistance indices in the middle cerebral arteries associated with increased cognitive impairments and positive amyloid status in AD and mild cognitively impaired patients, compared with healthy controls. This effect was independent of structural microvascular damage (i.e. atherosclerosis) as no decreases were detected in the retinal arteriolar-venular ratio [81]. However, it is possible that narrowing of arterioles as well as venules, from amyloid and collagenosis $[34,54]$, caused the ratio to remain the same as in healthy controls. In support of this, AD patients exhibit increased pulsatility and resistance in a variety of both afferent vessels, including the middle cerebral artery and internal carotid artery, and efferent vessels, including the superior sagittal, straight and transverse sinuses, visualized with 4D flow MRI [89,90].

Recently, van Veluw and colleagues demonstrated that clearance of an injected fluorescein dextran can be enhanced by evoking arterial vasomotion at $0.1 \mathrm{~Hz}$, with visual stimuli. This frequency of vasomotion occurs spontaneously in arterials, and correlates with ISF clearance [91-93]. Interestingly, AD mice with CAA do not exhibit enhanced clearance from evoked vasomotion, likely as a result of A $\beta$-related arterial stiffness, tortuosity and impaired pulsatility and resistance indices [16,57,81,89-91]. The authors did not observe $0.1 \mathrm{~Hz}$ spontaneous vasomotion in venules [91]; however, venular vasomotion from longer stimulations and/or a delayed response to arterial blood flow [92] may associate with and enhance perivenous ISF clearance [42,78]. Glymphatic perivenous clearance of the MRI contrast agent gadobutrol has recently been documented in humans. Meng and colleagues delivered gadobutrol to the ISF with MRI-guided focused ultrasound and observed clearance through the venular perivascular space, subarachnoid space and around draining veins [94]. Overall, vasomotive forces drive ISF clearance, and are impacted by A $\beta$ accumulation and AD-related cerebrovascular dysfunction. With venular amyloid and collagenosis there are dysfunctional vessel pulsations and decreased blood flow through the brain, which contribute to reduced periarterial and perivenous ISF solute clearance with $\mathrm{AD}$ progression.

\subsection{Enlargements in the Perivascular Space}

Soluble $A \beta$ in the ISF clears from the brain within arterial and venous perivascular spaces (also referred to as Virchow-Robin spaces) which surround small cerebral vessels [31,39,41,42,78]. Flow through these fluid-filled compartments is impeded by perivascular accumulation of cellular debris, as well as from amyloid and collagen aggregates on vessel walls. A loss of perivascular AQP4 channels occurs in AD patients, indicating reduced glymphatic CSF-ISF exchange and flow [31,95-97]. Finally, perivascular spaces are enlarged with age and $\mathrm{AD}$ pathology, and become visually detectable on MRI scans [31,98,99].

Banerjee and colleagues suggest that MRI-visible perivascular spaces in Alzheimer's disease are a result of cerebrovascular dysfunction, specifically small vessel disease co-morbidities, as they observed no association between amyloid burden and perivascular space enlargement [99]. However, others have reported strong associations; amyloid positron emission tomography (PET) and histopathology measurements colocalized with enlarged cortical perivascular spaces in cases of CAA and AD $[97,98,100,101]$. Support for this is seen in APP+PS1 rats, which exhibit a 1.7-fold increase in the perivascular space along frontal cortical vessels. Since this is an A $\beta$-driven model with 
venular amyloid, enlargements in the perivascular space are likely driven by A $\beta$ [53]. Additionally, tortuosity, a common cerebrovascular structural abnormality common in leukoaraiosis and AD, creates cavities in the surrounding brain parenchyma [16], potentially contributing to enlarged perivascular spaces. In the TgCRND8 mouse model of AD, arterial tortuosity occurs as a direct result of arterial $A \beta$ deposition [57], and venular tortuosity occurs from pharmacological depletion of mural cells, which are lost in $\mathrm{AD}$ patients $[45,87,88]$. Therefore, vascular amyloid accumulation contributes to the enlargement of perivascular spaces, and through impaired $A \beta$ clearance, enlarged perivascular spaces likely enhance vascular $A \beta$ deposition.

Venular amyloid and associated dysfunction in the venous system, including collagenosis, high pulsatility and resistance indices, and enlarged perivascular spaces, impair the efflux of ISF and A $\beta$ from the brain, and thereby act in a positive-feedback loop exacerbating $A \beta$ deposition and vascular dysfunction (Figure 2). Considering that vascular deficits are common co-morbidities of AD [16,30], there is a need for effective AD therapeutics that target the removal of vascular amyloid.

\section{Limited Efficacy of A $\beta$-Targeted Therapeutics on Vascular Amyloid}

A $\beta$-targeted treatments have been a focal point of AD therapeutic design for the last two decades. Despite some recent success with Aducanumab reducing cognitive decline, this class of therapeutics have been limited in disease modifying and clinically beneficial effects. Potential explanations include that $\mathrm{A} \beta$-targeted therapeutics were characterized in primarily $\mathrm{A} \beta$-driven preclinical models, targeted too late in disease progression in $\mathrm{AD}$ patients, and that the contributions of tau pathology to neurodegeneration and cognitive impairment persist with $A \beta$ attenuation [13]. However, one mostly overlooked factor is that most $A \beta$-targeted therapeutics do not remove vascular amyloid.

The first $A \beta$ immunotherapy to enter the clinic for AD was AN-1792, which involved active immunization with the full-length $A \beta$ peptide. AN-1792 led to acute and long-term reduction of parenchymal $A \beta$ plaques, exhibiting almost complete plaque clearance 14 years after treatment $[102,103]$. However, vascular amyloid was not attenuated and there was persistent and severe CAA in most patients [102,103]. Cerebral cortical and leptomeningeal vessel walls exhibited more complete A $\beta$ coverage and a significantly greater number of $A \beta 42$ positive vessels ( $14 \times$ and $7 \times$ more, respectively) in immunized compared to non-immunized AD patients [104]. Interestingly, A $\beta 42$ is normally absent in vascular amyloid deposits, and therefore these results suggest that $A \beta$ is solubilized from parenchymal plaques and accumulates along blood vessels during ISF clearance [41,42,104,105]. Conversely, Bapineuzumab passive immunization of an antibody to the same $A \beta$ antigenic site in AD patients reduced CAA on amyloid PET imaging, but was associated with a large degree of amyloid-related imaging abnormalities and vasogenic edema, with no clinical cognitive benefit [106-108], reviewed in [109]. Considering how venular amyloid-related impairments (i.e. collagenosis, impaired blood pulsation/flow, enlarged perivascular spaces) can impair clearance and increase vascular A $\beta$ deposition, $A \beta$-targeted therapeutics going forward should be designed to reduce vascular amyloid as well.

The only passive A $\beta$ immunotherapy directly investigated for CAA was Ponezumab, which specifically targets vascular $A \beta$. Ponezumab is a monoclonal antibody against $A \beta 40[110,111]$, which is the primary $A \beta$ species in CAA $[19,105]$. Initial results in AD rodent models with CAA were promising, including the reduction of $A \beta$-positive leptomeningeal and cortical vessels, reduced vascular soluble $A \beta 40$ and $A \beta 42$, improved hypercapnic response, and only transiently increased $A \beta 40$ in the ISF, indicating functioning perivascular/glymphatic $A \beta$ clearance [110]. However, in cases of probable CAA, Ponezumab treatment exacerbated impairments in cerebrovascular reactivity in response to visual stimuli, measured by blood-oxygen-level-dependent functional MRI signal in the visual cortex [111]. CAA was not assessed, but results suggest that target engagement was limited $[111,112]$. The Ponezumab results reveal the complicated nature of targeting vascular $A \beta$ in $\mathrm{CAA}$ and $\mathrm{AD}$, and demonstrate the potential need for alternatives to $\mathrm{A} \beta$ immunotherapy.

Another class of $\mathrm{A} \beta$-targeted therapeutics are beta-site APP cleaving enzyme 1 (BACE1; $\beta$-secretase) inhibitors which reduce the production of $A \beta$ [113]. BACE1 is expressed in cerebrovascular 
associated cells on leptomeningeal and cortical vessels, including smooth muscle and endothelial cells [114]. Furthermore, leptomeningeal vessels extracted from patients with CAA exhibit elevated BACE1 levels and activity [114]. Thus, data demonstrate a potential role of BACE1 in vessel-localized A $\beta$ production and vascular $A \beta$ deposition. The BACE1 inhibitor NB-360 attenuates $A \beta$ in preclinical AD models [115,116], and was recently investigated in the APPDutch CAA mouse model [117]. APPDutch mice develop leptomeningeal and cortical CAA composed primarily of A $\beta 40$, without exhibiting parenchymal plaques. It is unconfirmed whether venular amyloid is present in this model $[117,118]$. NB-360 treatment at the age of CAA onset reduced score, frequency, and severity of CAA measured by immunohistochemistry, with a $90 \%$ reduction of CSF A $\beta$ [117]. Importantly, once cleared from the blood vessels, $\mathrm{A} \beta$ was not deposited in parenchymal plaques [117]. Smooth muscle cell loss was attenuated and microhemorrhages were not exacerbated by NB-360 treatment $[117,119]$, indicating rescue of amyloid-associated cerebrovascular impairment. More work is needed to determine the efficacy of NB-360 as a therapeutic intervention when CAA has already accumulated. Currently, BACE1 inhibitors have failed to improve cognition in AD patients [120], and therefore these results demonstrate the potential role for BACE1 inhibitors specifically in cases of CAA and warrant further investigation.

\section{Conclusions}

Most cases of AD exhibit presence of cerebrovascular amyloid (i.e. CAA) and are often co-morbid with cerebrovascular diseases [8,30]. To date, research has attributed CAA to pathology in arteries and arterioles, with veins having a minimal role [24,34]. However, several papers have presented data demonstrating vascular amyloid in veins and venules in both preclinical animal models and clinical case studies $[27,50,51,53]$. In preclinical models, the presence of venular amyloid, in combination with the decreased vascular reactivity [18] and venular degeneration [45] further supports the potential role of the draining vessels in AD.

Despite the differences in preclinical experiments, clinical studies of venular amyloid provides evidence for the involvement of veins in CAA severity and AD [24,34,50,51]. We highlight several mechanisms that may increase venular amyloid deposition and contribute to venular pathology. Venous collagenosis, impaired cerebrovascular pulsatility and vasomotion, and enlarged perivascular spaces contribute to AD-related cerebrovascular dysfunction and may be associated with arterial and venular amyloid, suggesting further disturbance in the clearance of $A \beta$ along the perivascular drainage pathway (Figure 2) $[30,47,53,54,81,99]$. Overall, we propose that these mechanisms act in a positive-feedback loop, promoting venular $A \beta$ deposition and vice versa.

Herein, we propose venular amyloid is an integral part of AD pathology, and that numerous mechanisms related to the pathophysiology of veins (i.e. venous collagenosis, impaired cerebrovascular pulsatility, enlarged perivascular spaces) may lend further insight into the cerebrovasculature dysfunction in AD. This critical role of vascular pathology could help explain the limited efficacy of $A \beta$-targeted therapeutics, as they typically do not remove vascular amyloid. Improvements in arterial and venular classifications, appropriate choices of preclinical models and treatment design oriented towards removing vascular $\mathrm{A} \beta$, will benefit $\mathrm{CAA}$ and $\mathrm{AD}$ research going forward. Recognizing the importance of venular, as well as arterial, amyloid in $\mathrm{AD}$ pathogenesis will be integral to increase treatment specificity and efficacy, and to gain a comprehensive understanding of disease progression.

Author Contributions: Conceptualization: C.D.M., J.B., and J.M.; Writing-Original Draft Preparation: C.D.M. and J.B.; Writing-Review and Editing: C.D.M., J.B., and J.M.; J.B. acquired images and compiled Figure 1.; C.D.M., J.B., and J.M. designed Figure 2.; C.D.M. and J.M. supervised, edited and approved the review. All authors have read and agreed to the published version of the manuscript.

Funding: This work was supported by funding from: Canadian Institutes of Health Research Project Grant, PJY153101, Canada Research Chairs Program and National Institutes of Health R01 AG057665-02.

Acknowledgments: We acknowledge Aaron Lai for discussions and his expertise on cerebrovascular dysfunction and vascular amyloid in Alzheimer's disease. We thank Sherry Lai for the illustration.

Conflicts of Interest: The authors declare no conflict of interest. 


\section{Abbreviations}

$\begin{array}{ll}\alpha \text {-SMA } & \text { alpha-smooth muscle actin } \\ \text { A } \beta & \text { amyloid-beta } \\ \text { AD } & \text { Alzheimer's disease } \\ \text { APP } & \text { amyloid precursor protein } \\ \text { AQP4 } & \text { aquaporin } 4 \\ \text { BACE1 } & \text { beta-site amyloid precursor protein cleaving enzyme 1 } \\ \text { BBB } & \text { blood-brain barrier } \\ \text { CAA } & \text { cerebral amyloid angiopathy } \\ \text { CSF } & \text { cerebrospinal fluid } \\ \text { HCHWA } & \text { hereditary cerebral hemorrhage with amyloidosis } \\ \text { ISF } & \text { interstitial fluid } \\ \text { MRI } & \text { magnetic resonance imaging } \\ \text { PET } & \text { positron emission tomography } \\ \text { PS1/PS2 } & \text { presenilin-1/ -2 }\end{array}$

\section{References}

1. Iadecola, C.; Gorelick, P.B. Mechanisms in Vascular and Neurodegenerative Dementia. Stroke 2003, 34, 335-337. [CrossRef] [PubMed]

2. Saito, S.; Ihara, M. New Therapeutic Approaches for Alzhiemer's disease and Cerebral Amyloid Angiopathy. Front. Aging Neurosci. 2014, 6, 290. [CrossRef] [PubMed]

3. Querfurth, H.W.; LaFerla, F.M. Alzheimer's Disease. N. Engl. J. Med. 2010, 362, 329-344. [CrossRef] [PubMed]

4. Weller, R.O.; Subash, M.; Preston, S.D.; Mazanti, I.; Carare, R.O. SYMPOSIUM: Clearance of A $\beta$ from the Brain in Alzheimer's Disease: Perivascular Drainage of Amyloid- $\beta$ Peptides from the Brain and its Failure in Cerebral Amyloid Angiopathy and Alzheimer's Disease. Brain Pathol. 2008, 18, 253-266. [CrossRef]

5. Cai, Y.; An, S.S.; Kim, S. Mutations in presenilin 2 and its implications in Alzheimer's disease and other dementia-Associated disorders. Clin. Interv. Aging 2015, 10, 1163-1172. [CrossRef]

6. Kelleher, R.J.; Shen, J. Presenilin-I mutations and Alzheimer's disease. Proc. Natl. Acad. Sci. USA 2017, 114, 629-631. [CrossRef]

7. Bekris, L.M.; Yu, C.; Bird, T.D.; Tsuang, D.W. Genetics of Alzheimer's Disease. J. Geriatr. Psychiatry Neurol. 2010, 23, 213-227. [CrossRef]

8. Biffi, A.; Greenberg, S.M. Cerebral Amyloid Angiopathy: A Systemic Review. J. Clin. Neurol. 2011, 7, 1-9. [CrossRef]

9. Thal, D.R.; Rüb, U.; Orantes, M.; Braak, H. Phases of A $\beta$-Deposition in the human brain and its relevance for the development of AD. Neurology 2002, 58, 1791-1800. [CrossRef]

10. Hunter, J.M.; Kwan, J.; Malek-Ahmadi, M.; Maarouf, C.L.; Kokjohn, T.A.; Belden, C.; Sabbagh, M.N.; Beach, T.G.; Roher, A.E. Morphological and Pathological Evolution of the Brain Microcirculation in Aging and Alzheimer's Disease. PLoS ONE 2012, 7, e36893. [CrossRef]

11. O'Brien, R.J.; Wong, P.C. Amyloid Precursor Protein Processing and Alzheimer's Disease. Annu. Rev. Neurosci. 2011, 34, 185-204. [CrossRef] [PubMed]

12. Bateman, R.J.; Xiong, C.; Benzinger, T.L.S.; Fagan, A.M.; Goate, A.; Fox, N.C.; Marcus, D.S.; Cairns, N.J.; Xie, X.; Blazey, T.M.; et al. Dominantly Inherited Alzheimer Network. Clinical and Biomarker Changes in Dominantly Inherited Alzheimer's Disease. N. Engl. J. Med. 2012, 367, 794-804. [CrossRef] [PubMed]

13. Morrone, C.D.; Bazzigaluppi, P.; Beckett, T.L.; Hill, M.E.; Koletar, M.M.; Stefanovic, B.; McLaurin, J. Regional differences in Alzheimer's disease pathology confound behavioural rescue after amyloid- $\beta$ attenuation. Brain 2020, 143, 359-373. [CrossRef] [PubMed]

14. Selkoe, D.J.; Hardy, J. The amyloid hypothesis of Alzheimer's disease at 25 years. EMBO Mol. Med. 2016, 8, 595-608. [CrossRef] [PubMed]

15. Brown, W.R.; Moody, D.M.; Thore, C.R.; Anstrom, J.A.; Challa, V.R. Microvascular changes in the white mater in dementia. J. Neurol. Sci. 2009, 283, 28-31. [CrossRef] [PubMed] 
16. Brown, W.R.; Thore, C.R. Review: Cerebral microvascular pathology in ageing and neurodegeneration. Neuropathol. Appl. Neurobiol. 2012, 37, 56-74. [CrossRef]

17. Iturria-Medina, Y.; Sotero, R.C.; Toussaint, P.J.; Mateos-Pérez, J.M.; Evans, A.C.; The Alzheimer's Disease Neuroimaging Initiative. Early role of vascular dysregulation on late-Onset Alzheimer's disease based on multifactorial data-Driven analysis. Nat. Commun. 2016, 7, 11934. [CrossRef]

18. Joo, I.L.; Lai, A.Y.; Bazzigaluppi, P.; Koletar, M.M.; Dorr, A.; Brown, M.E.; Thomason, L.A.M.; Sled, J.G.; McLaurin, J.; Stefanovic, B. Early neurovascular dysfunction in a transgenic rat model of Alzheimer's disease. Sci. Rep. 2017, 7, 46427. [CrossRef]

19. Revesz, T.; Holton, J.L.; Lashley, T.; Plant, G.; Rostagno, A.; Ghiso, J.; Frangione, B. Sporadic and Familial Cerebral Amyloid Angiopathies. Brain Pathol. 2002, 12, 343-357. [CrossRef]

20. Revesz, T.; Holton, J.L.; Lashley, T.; Plant, G.; Frangione, B.; Rostagno, A.; Ghiso, J. Genetics and molecular pathogenesis of sporadic and hereditary cerebral amyloid angiopathy. Acta Neuropathol. 2009, 118, 115-130. [CrossRef]

21. Banerjee, G.; Carare, R.; Cordonnier, C.; Greenberg, S.M.; Schneider, J.A.; Smith, E.E.; Buchem, M.V.; Grond, J.V.; Verbeek, M.M.; Werring, D.J. The increasing impact of cerebral amyloid angiopathy: Essential new insights for clinical practice. J. Neurol. Neurosurg. Psychiatry 2017, 88, 982-994. [CrossRef] [PubMed]

22. Greenberg, S.M.; Bacskai, B.J.; Hernandez-Guillamon, M.H.; Pruzin, J.; Sperling, R.; van Veluw, S.J. Cerebral amyloid angiopathy and Alzheimer disease-One peptide, two pathways. Nat. Rev. Neurol. 2020, 16, 30-42. [CrossRef] [PubMed]

23. Charidimou, A.; Boulouis, G.; Gurol, M.E.; Ayata, C.; Bacskai, B.J.; Frosch, M.P.; Viswanathan, A.; Greenberg, S.M. Emerging concepts in sporadic cerebral amyloid angiopathy. Brain 2017, 140, 1829-1850. [CrossRef] [PubMed]

24. Weller, R.O.; Boche, D.; Nicoll, J.A.R. Microvasculature changes and cerebral amyloid angiopathy in Alzheimer's disease and their potential impact on therapy. Acta Neuropathol. 2009, 118, 87-102. [CrossRef] [PubMed]

25. Scholz, W. Studien zur Pathologie der Hirngefässe II. Die drusige Entartung der Hirnarterien und Capillaren. Z. Ges. Neurol. Psychiat. 1938, 162, 694-715. [CrossRef]

26. Pantelakis, S. A particular type of senile angiopathy of the central nervous system: Congophilic angiopathy, topography and frequency. Monatsschr. Psychiatr. Neurol. 1954, 128, 219-256. [CrossRef]

27. Michaud, J.P.; Bellavance, M.A.; Préfontaine, P.; Rivest, S. Real-Time In Vivo Imaging Reveals the Ability of Monocytes to Clear Vascular Amyloid Beta. Cell Rep. 2013, 5, 646-653. [CrossRef]

28. McGowan, E.; Pickford, F.; Kim, J.; Onstead, L.; Eriksen, J.; Yu, C.; Skipper, L.; Murphy, M.P.; Beard, J.; Das, P.; et al. Abeta42 is essential for parenchymal and vascular amyloid deposition in mice. Neuron 2005, 47, 191-199. [CrossRef]

29. Attems, J.; Lintner, F.; Jellinger, K.A. Amyloid beta peptide 1-42 highly correlates with capillary cerebral amyloid angiopathy and Alzheimer disease pathology. Acta. Neuropathol. 2004, 107, 283-291. [CrossRef]

30. Black, S.; Gao, F.; Bilbao, J. Understanding White Matter Disease: Imaging-Pathological Correlations in Vascular Cognitive Impairment. Stroke 2009, 40, S48-S52. [CrossRef]

31. Brown, R.; Benveniste, H.; Black, S.E.; Charpak, S.; Dichgans, M.; Joutel, A.; Nedergaard, M.; Smith, K.J.; Zlokovic, B.V.; Wardlaw, J.M. Understanding the role of the perivascular space in cerebral small vessel disease. Cardiovasc. Res. 2018, 114, 1462-1473. [CrossRef] [PubMed]

32. Charidimou, A.; Pantoni, L.; Love, S. The concept of sporadic cerebral small vessel disease: A road map on key definitions and current concepts. Int. J. Stroke 2016, 11, 6-18. [CrossRef] [PubMed]

33. Pantoni, L. Cerebral small vessel disease: From pathogenesis and clinical characteristics to therapeutic challenges. Lancet Neurol. 2010, 9, 689-701. [CrossRef]

34. Weller, R.O.; Massey, A.; Newman, T.A.; Hutchings, M.; Kuo, Y.; Roher, A.E. Cerebral Amyloid Angiopathy: Amyloid $\beta$ Accumulates in Putative Interstitial Fluid Drainage Pathways in Alzheimer's Disease. Am. J. Pathol. 1998, 153, 725-733. [CrossRef]

35. Yates, P.A.; Desmond, P.M.; Phal, P.M.; Steward, C.; Szoeke, C.; Salvado, O.; Ellis, K.A.; Martins, R.N.; Masters, C.L.; Ames, D.; et al. AIBL Research Group. Incidence of cerebral microbleeds in preclinical Alzheimer disease. Neurology 2014, 82, 1266-1273. [CrossRef]

36. Hawkes, C.A.; Jayakody, N.; Johnston, D.A.; Bechmann, I.; Carare, R.O. Failure of Perivascular Drainage of $\beta$-amyloid in Cerebral Amyloid Angiopathy. Brain Pathol. 2014, 24, 396-403. [CrossRef] 
37. Hawkes, C.A.; Härtig, W.; Kacza, J.; Schliebs, R.; Weller, R.O.; Nicoll, J.A.; Carare, R.O. Perivascular drainage of solutes is impaired in the ageing mouse brain and in the presence of cerebral amyloid angiopathy. Acta Neuropathol. 2011, 121, 431-443. [CrossRef]

38. Peng, W.; Achariyar, T.M.; Li, B.; Liao, Y.; Mestre, H.; Hitomi, E.; Regan, S.; Kasper, T.; Peng, S.; Ding, F.; et al. Suppression of glymphatic fluid transport in a mouse model of Alzheimer's disease. Neurobiol. Dis. 2016, 93, 215-225. [CrossRef]

39. Morrone, C.D.; Liu, M.; Black, S.E.; McLaurin, J. Interaction between therapeutic interventions for Alzheimer's disease and physiological A $\beta$ clearance mechanisms. Front. Aging Neurosci. 2015, 7, 64. [CrossRef]

40. Horsburgh, K.; Wardlaw, J.M.; Agtmael, T.V.; Allan, S.M.; Ashford, M.L.J.; Bath, P.M.; Brown, R.; Berwick, J.; Cader, M.Z.; Carare, R.O.; et al. Small vessels, dementia and chronic diseases-Molecular mechanisms and pathophysiology. Clin. Sci. (Lond.) 2018, 132, 851-868. [CrossRef]

41. Carare, R.O.; Bernardes-Silva, M.; Newman, T.A.; Page, A.M.; Nicoll, J.A.R.; Perry, V.H.; Weller, R.O. Solutes, but not cells, drain from the brain parenchyma along basement membranes of capillaries and arteries: Significance for cerebral amyloid angiopathy and neuroimmunology. Neuropathol. Appl. Neurobiol. 2008, 34, 131-144. [CrossRef] [PubMed]

42. Iliff, J.J.; Wang, M.; Liao, Y.; Plogg, B.A.; Peng, W.; Gundersen, G.A.; Benveniste, H.; Vates, G.E.; Deane, R.; Goldman, S.A.; et al. A Paravascular Pathway Facilitates CSF Flow Through the Brain Parenchyma and the Clearance of Interstitial Solutes, Including Amyloid ß. Sci. Transl. Med. 2012, 4, 147ra111. [CrossRef] [PubMed]

43. Tarasoff-Conway, J.M.; Carare, R.O.; Osorio, R.S.; Glodzik, L.; Butler, T.; Fieremans, E.; Axel, L.; Rusinek, H.; Nicholson, C.; Zlokovic, B.V.; et al. Clearance systems in the brain-implications for Alzheimer's disease. Nat. Rev. Neurol. 2015, 11, 457-470. [CrossRef] [PubMed]

44. MacGregor Sharp, M.; Criswell, T.P.; Dobson, H.; Finucane, C.; Verma, A.; Carare, R.O. Solving an Old Dogma: Is it an Arteriole or a Venule? Front. Aging Neurosci. 2019, 11, 289. [CrossRef]

45. Lai, A.Y.; Dorr, A.; Thomason, L.A.M.; Koletar, M.M.; Sled, J.G.; Stefanovic, B.; McLaurin, J. Venular degeneration leads to vascular dysfunction in a transgenic model of Alzheimer's disease. Brain 2015, 138, 1046-1058. [CrossRef]

46. Hartmann, D.A.; Hyacinth, H.I.; Liao, F.F.; Shih, A.Y. Does pathology of small venules contribute to cerebral infarcts and dementia? J. Neurochem. 2018, 144, 517-526. [CrossRef]

47. Keith, J.; Gao, F.; Noor, R.; Kiss, A.; Balasubramaniam, G.; Au, K.; Rogaeva, E.; Masellis, M.; Black, S.E. Collagenosis of the Deep Medullary Veins: An Underrecognized Pathologic Correlate of White Matter Hyperintensities and Periventricular Infarction? J. Neuropathol. Exp. Neurol. 2017, 76, 299-312. [CrossRef]

48. Simka, M.; Skula, M. Potential Involvement of Impaired Venous Outflow from the Brain in Neurodegeneration: Lessons Learned from the Research on Chronic Cerebrospinal Venous Insufficiency. Rev. Recent Clin. Trials 2019, 14, 235-236. [CrossRef]

49. Mountjoy, C.Q.; Tomlinson, B.E.; Gibson, P.H. Amyloid and Senile Plaques and Cerebral Blood Vessels. A Semi-Quantitative Investigation of a Possible Relationship. J. Neurol. Sci. 1982, 57, 89-103. [CrossRef]

50. Mendel, T.; Wierzba-Bobrowicz, T.; Stępień, T.; Szpak, G.M. $\beta$-Amyloid deposits in veins in patients with cerebral amyloid angiopathy and intracerebral haemorrhage. Folia Neuropathol. 2013, 51, 120-126. [CrossRef]

51. Thal, D.R.; Ghebremedhin, E.; Rüb, U.; Yamaguchi, H.; Del Tredici, K.; Braak, H. Two Types of Sporadic Cerebral Amyloid Angiopathy. J. Neuropathol. Exp. Neurol. 2002, 61, 282-293. [CrossRef] [PubMed]

52. Moody, D.M.; Brown, W.R.; Challa, V.R.; Anderson, R.L. Periventricular venous collagenosis: Association with leukoaraiosis. Radiology 1995, 194, 469-476. [CrossRef] [PubMed]

53. Klakotskaia, D.; Agca, C.; Richardson, R.A.; Stopa, E.G.; Schachtman, T.R.; Agca, Y. Memory deficiency, cerebral amyloid angiopathy, and amyloid- $\beta$ plaques in APP+PS1 double transgenic rat model of Alzheimer's disease. PLoS ONE 2018, 13, e0195469. [CrossRef] [PubMed]

54. Moody, D.M.; Brown, W.R.; Challa, V.R.; Ghazi-Birry, H.S.; Reboussin, D.M. Cerebral Microvascular Alterations in Aging, Leukoaraiosis, and Alzheimer's Disease. Ann. N. Y. Acad. Sci. 1997, 826, 103-116. [CrossRef]

55. Gao, F.; van Gaal, S.; Levy-Cooperman, N.; Ramirez, J.; Scott, C.J.M.; Bilbao, J.; Black, S.E. P2-010: Does variable progression of incidental white matter hyperintensities in AD relate to venous insufficiency? In Proceedings of the Alzheimer's Association International Conference on Alzheimer's Disease (Alzheimers Dement), Chicago, IL, USA, 26-31 July 2008; pp. T368-T369. [CrossRef] 
56. Cohen, R.M.; Rezai-Zadeh, K.; Weitz, T.M.; Rentsendorj, A.; Gate, D.; Spivak, I.; Bholat, Y.; Vasilevko, V.; Glabe, C.G.; Breunig, J.J.; et al. A transgenic Alzheimer rat with plaques, tau pathology, behavioral impairment, oligomeric A $\beta$ and frank neuronal loss. J. Neurosci. 2013, 33, 6245-6256. [CrossRef]

57. Dorr, A.; Sahota, B.; Chinta, L.V.; Brown, M.E.; Lai, A.Y.; Ma, K.; Hawkes, C.A.; McLaurin, J.; Stefanovic, B. Amyloid- $\beta$-Dependent compromise of microvascular structure and function in a model of Alzheimer's disease. Brain 2012, 135, 3039-3050. [CrossRef]

58. Kress, B.T.; Iliff, J.J.; Xia, M.; Wang, M.; Wei, H.; Zeppenfeld, D.; Xie, L.; Kang, H.; Xu, Q.; Liew, J.; et al. Impairment of paravascular clearance pathways in the aging brain. Ann. Neurol. 2014, 76, 845-861. [CrossRef]

59. Van Dorpe, J.; Smeijers, L.; Dewachter, I.; Nuyens, D.; Spittaels, K.; Van Den Haute, C.; Mercken, M.; Moechars, D.; Laenen, I.; Kuiperi, C.; et al. Prominent cerebral amyloid angiopathy in transgenic mice overexpressing the london mutant of human APP in neurons. Am. J. Pathol. 2000, 157, 1283-1298. [CrossRef]

60. Giannoni, P.; Arango-Lievano, M.; Neves, I.D.; Rousset, M.C.; Barranger, K.; Rivera, S.; Jeanneteau, F.; Claeysen, S.; Marchi, N. Cerebrovascular pathology during the pro gression of experimental Alzheimer's disease. Neurobiol. Dis. 2016, 88, 107-117. [CrossRef]

61. Heo, C.H.; Sarkar, A.R.; Baik, S.H.; Jung, T.S.; Kim, J.J.; Kang, H.; Mook-Jung, I.; Kim, H.M. A quadrupolar two-Photon fluorescent probe for in vivo imaging of amyloid- $\beta$ plaques. Chem. Sci. 2016, 7, 4600-4606. [CrossRef]

62. Herzig, M.C.; Winkler, D.T.; Burgermeister, P.; Pfeifer, M.; Kohler, E.; Schmidt, S.D.; Danner, S.; Abramowski, D.; Stürchler-Pierrat, C.; Bürki, K.; et al. Abeta is targeted to the vasculature in a mouse model of hereditary cerebral hemorrhage with amyloidosis. Nat. Neurosci. 2004, 7, 954-960. [CrossRef] [PubMed]

63. Davis, J.; Xu, F.; Deane, R.; Romanov, G.; Previti, M.L.; Zeigler, K.; Zlokovic, B.V.; Nostrand, W.E.V. Early-Onset and robust cerebral microvascular accumulation of amyloid beta-protein in transgenic mice expressing low levels of a vasculotropic Dutch/Iowa mutant form of amyloid beta-Protein precursor. J. Biol. Chem. 2004, 279, 20296-20306. [CrossRef] [PubMed]

64. El Tannir El Tayara, N.; Delatour, B.; Volk, A.; Dhenain, M. Detection of vascular alterations by in vivo magnetic resonance angiopathy and histology in APP/PS1 mouse model of Alzheimer's disease. Magn. Reson. Mater. Phy. 2010, 23, 53-64. [CrossRef] [PubMed]

65. Calhoun, M.E.; Burgermeister, P.; Phinney, A.L.; Stalder, M.; Tolnay, M.; Wiederhold, K.H.; Abramowski, D.; Stürchler-Pierrat, C.; Sommer, B.; Staufenbiel, M.; et al. Neuronal overexpression of mutant amyloid precursor protein results in prominent deposition of cerebrovascular amyloid. Proc. Natl. Acad. Sci. USA 1999, 23, 14088-14093. [CrossRef] [PubMed]

66. Kuo, Y.M.; Beach, T.G.; Sue, L.I.; Scott, S.; Layne, K.J.; Kokjohn, T.A.; Abramowski, D.; Stürchler-Pierrat, C.; Staufenbiel, M.; Weller, R.O.; et al. The evolution of Abeta peptide burden in the APP23 transgenic mice: Implications for Abeta deposition in Alzheimer disease. Mol. Med. 2001, 7, 609-618. [CrossRef] [PubMed]

67. Suter, O.C.; Sunthorn, T.; Kraftsik, R.; Straubel, J.; Darekar, P.; Khalili, K.; Miklossy, J. Cerebral hypoperfusion generates cortical watershed microinfarcts in Alzheimer's disease. Stroke 2002, 33, 1986-1992. [CrossRef] [PubMed]

68. Shih, A.Y.; Rühlmann, C.; Blinder, P.; Devor, A.; Drew, P.J.; Friedman, B.; Knutsen, P.M.; Lyden, P.D.; Matéo, C.; Mellander, L.; et al. Robust and Fragile Aspects of Cortical Blood Flow in Relation to the Underlying Angioarchitecture. Microcirculation 2015, 22, 204-218. [CrossRef]

69. Nguyen, J.; Nishimura, N.; Fetcho, R.N.; Iadecola, C.; Schaffer, C.B. Occlusion of cortical ascending venules causes blood flow decreases, reversals in flow direction, and vessel dilation in upstream capillaries. J. Cereb. Blood. Flow. Metab. 2011, 31, 2243-2254. [CrossRef]

70. Shih, A.Y.; Blinder, P.; Tsai, P.S.; Friedman, B.; Stanley, G.; Lyden, P.D.; Kleinfeld, D. The smallest stroke: Occlusion of one penetrating vessel leads to infarction and a cognitive deficit. Nat. Neurosci. 2013, 16, 55-63. [CrossRef]

71. Summers, P.M.; Hartmann, D.A.; Hui, E.S.; Nie, X.; Deardorff, R.L.; McKinnon, E.T.; Helpern, J.A.; Jensen, J.H.; Shih, A.Y. Functional deficits induced by cortical microinfarcts. J. Cereb. Blood Flow Metab. 2017, 37, 3599-3614. [CrossRef]

72. Blinder, P.; Tsai, P.S.; Kaufhold, J.P.; Knutsen, P.M.; Suhl, H.; Kleinfeld, D. The cortical angiome: An interconnected vascular network with noncolumnar patterns of blood flow. Nat. Neurosci. 2013, 16, 889-897. [CrossRef] [PubMed] 
73. Brown, W.R.; Moody, D.M.; Challa, V.R.; Thore, C.R.; Anstrom, J.A. Venous collagenosis and arteriolar tortuosity in leukoaraiosis. J. Neurol. Sci. 2002, 203-204, 159-163. [CrossRef]

74. Yoshita, M.; Fletcher, E.; Harvey, D.; Ortega, M.; Martinez, O.; Mungas, D.M.; Reed, B.R.; DeCarli, C.S. Extent and distribution of white matter hyperintensities in normal aging, MCI, and AD. Neurology 2006, 67, 2192-2198. [CrossRef] [PubMed]

75. Yan, S.; Wan, J.; Zhang, X.; Tong, L.; Zhao, S.; Sun, J.; Lin, Y.; Shen, C.; Lou, M. Increased Visibility of Deep Medullary Veins in Leukoaraisos: A 3-T MRI Study. Front. Aging Neurosci. 2014, 6, 144. [CrossRef] [PubMed]

76. Pettersen, J.A.; Keith, J.; Gao, F.; Spence, J.D.; Black, S.E. CADASIL accelerated by acute hypotension: Arterial and venous contribution to leukoaraiosis. Neurology 2017, 88, 1077-1080. [CrossRef] [PubMed]

77. Houck, A.L.; Gutierrez, J.; Gao, F.; Igwe, K.C.; Colon, J.M.; Black, S.E.; Brickman, A.M. Increased Diameters of the Internal Cerebral Veins and the Basal Veins of Rosenthal Are Associated with White Matter Hyperintensity Volume. AJNR. Am. J. Neuroradiol. 2019, 40, 1712-1718. [CrossRef] [PubMed]

78. Abbott, N.J.; Pizzo, M.E.; Preston, J.E.; Janigro, D.; Thorne, R.G. The role of brain barriers in fluid movement in the CNS: Is there a 'glymphatic' system? Acta Neuropathol. 2018, 135, 387-407. [CrossRef]

79. Touyz, R.M.; Briones, A.M. Reactive oxygen species and vascular biology: Implications in human hypertension. Hypertens. Res. 2011, 34, 5-14. [CrossRef]

80. Roher, A.E.; Garami, Z.; Alexandrov, A.V.; Kokjohn, T.A.; Esh, C.L.; Kalback, W.M.; Vedders, L.J.; Wilson, J.R.; Sabbagh, M.N.; Beach, T.G. Interaction of cardiovascular disease and neurodegeneration: Transcranial Doppler ultrasonography and Alzheimer's disease. Neurol. Res. 2006, 28, 672-678. [CrossRef]

81. Ortner, M.; Hauser, C.; Schmaderer, C.; Muggenthaler, C.; Hapfelmeier, A.; Sorg, C.; Diehl-Schmid, J.; Kurz, A.; Förstl, H.; Ikenberg, B.; et al. Decreased Vascular Pulsatility in Alzheimer's Disease Dementia Measured by Transcranial Color-Coded Duplex Sonography. Neuropsychiatr. Dis. Treat. 2019, 15, 3487-3499. [CrossRef]

82. Henry-Feugeas, M.C. Alzheimer's disease in late life dementia: A minor toxic consequence of devastating cerebrovascular dysfunction. Med. Hypotheses 2008, 70, 866-875. [CrossRef] [PubMed]

83. Criswell, T.P.; Sharp, M.M.; Dobson, H.; Finucane, C.; Weller, R.O.; Verma, A.; Carare, R.O. The structure of the perivascular compartment in the old canine brain: A case study. Clin. Sci. (Lond.) 2017, 11, 2737-2744. [CrossRef] [PubMed]

84. Verbeek, M.M.; Van Nostrand, W.E.; Otte-Höller, I.; Wesseling, P.; De Waal, R.M. Amyloid-Beta-Induced degeneration of human brain pericytes is dependent on apolipoprotein E genotype. Ann. N. Y. Acad. Sci. 2000, 903, 187-199. [CrossRef] [PubMed]

85. Bruinsma, I.B.; Wilhelmus, M.M.; Kox, M.; Veerhuis, R.; de Waal, R.M.; Verbeek, M.M. Apoplipoprotein E protects cultured pericytes and astrocytes from D-Abeta(1-40)-Mediated cell death. Brain Res. 2010, 1315, 169-180. [CrossRef] [PubMed]

86. Schultz, N.; Brännström, K.; Byman, E.; Moussaud, S.; Nielsen, H.M.; Netherlands Brain Bank; Olofsson, A.; Wennström, M. Amyloid-Beta 1-40 is associated with alterations in NG2+ pericyte population ex vivo and in vitro. Aging Cell 2018, 17, e12728. [CrossRef]

87. Sengillo, J.D.; Winkler, E.A.; Walker, C.T.; Sullivan, J.S.; Johnson, M.; Zlokovic, B.V. Deficiency in mural vascular cells coincides with blood-Brain barrier disruption in Alzheimer's disease. Brain Pathol. 2013, 23, 303-310. [CrossRef]

88. Bourassa, P.; Tremblay, C.; Schneider, J.A.; Bennett, D.A.; Calon, F. Brain mural cell loss in the parietal cortex in Alzheimer's disease correlates with cognitive decline and TDP-43 pathology. Neuropathol. Appl. Neurobiol. 2020. [CrossRef]

89. Rivera-Rivera, L.A.; Turski, P.; Johnson, K.M.; Hoffman, C.; Berman, S.E.; Kilgas, P.; Rowley, H.A.; Carlsson, C.M.; Johnson, S.C.; Wieben, O. 4D flow MRI for intracranial hemodynamics assessment in Alzheimer's disease. J. Cereb. Blood Flow Metab. 2016, 36, 1718-1730. [CrossRef]

90. Rivera-Rivera, L.A.; Schubert, T.; Turski, P.; Johnson, K.M.; Berman, S.E.; Rowley, H.A.; Carlsson, C.M.; Johnson, S.C.; Wieben, O. Changes in intracranial venous blood flow and pulsatility in Alzheimer's disease: A 4D flow MRI study. J. Cereb. Blood Flow Metab. 2017, 37, 2149-2158. [CrossRef]

91. van Veluw, S.J.; Hou, S.S.; Calvo-Rodriguez, M.; Arbel-Ornath, M.; Snyder, A.C.; Frosch, M.P.; Greenberg, S.M.; Bacskai, B.J. Vasomotion as a Driving Force for Paravascular Clearance in the Awake Mouse Brain. Neuron 2020, 105, 549-561. [CrossRef] 
92. Drew, P.J.; Shih, A.Y.; Kleinfeld, D. Fluctuating and sensory-Induced vasodynamics in rodent cortex extend arteriole capacity. Proc. Natl. Acad. Sci. USA 2011, 108, 8473-8478. [CrossRef] [PubMed]

93. Mateo, C.; Knutsen, P.M.; Tsai, P.S.; Shih, A.Y.; Kleinfeld, D. Entrainment of Arteriole Vasomotor Fluctuations by Neural Activity Is a Basis of Blood-Oxygenation-Level-Dependent "Resting-State" Connectivity. Neuron 2017, 96, 936-948. [CrossRef] [PubMed]

94. Meng, Y.; Abrahao, A.; Heyn, C.C.; Bethune, A.J.; Huang, Y.; Pople, C.B.; Aubert, I.; Hamani, C.; Zinman, L.; Hynynen, K.; et al. Glymphatics Visualization after Focused Ultrasound-Induced Blood-Brain Barrier Opening in Humans. Ann. Neurol. 2019, 86, 975-980. [CrossRef] [PubMed]

95. Ramirez, J.; Berezuk, C.; McNeely, A.A.; Gao, F.; McLaurin, J.; Black, S.E. Imaging the Perivascular Space as a Potential Biomarker of Neurovascular and Neurodegenerative Diseases. Cell Mol. Neurobiol. 2016, 36, 289-299. [CrossRef] [PubMed]

96. Mestre, H.; Kostrikov, S.; Mehta, R.I.; Nedergaard, M. Perivascular spaces, glymphatic dysfunction, and small vessel disease. Clin. Sci. (Lond.) 2017, 131, 2257-2274. [CrossRef] [PubMed]

97. Boespflug, E.L.; Simon, M.J.; Leonard, E.; Grafe, M.; Woltjer, R.; Silbert, L.C.; Kaye, J.A.; Iliff, J.J. Targeted Assessment of Enlargement of the Perivascular Space in Alzheimer's Disease and Vascular Dementia Subtypes Implicates Astroglial Involvement Specific to Alzheimer's Disease. J. Alzheimers Dis. 2018, 66, 1587-1597. [CrossRef] [PubMed]

98. Ramirez, J.; Berezuk, C.; McNeely, A.A.; Scott, C.J.; Gao, F.; Black, S.E. Visible Virchow-Robin spaces on magnetic resonance imaging of Alzheimer's disease patients and normal elderly from the Sunnybrook Dementia Study. J. Alzheimers Dis. 2015, 43, 415-424. [CrossRef]

99. Banerjee, G.; Kim, H.J.; Fox, Z.; Jäger, H.R.; Wilson, D.; Charidimou, A.; Na, H.K.; Na, D.L.; Seo, S.W.; Werring, D.J. MRI-Visible perivascular space location is associated with Alzheimer's disease independently of amyloid burden. Brain 2017, 140, 1107-1116. [CrossRef]

100. Charidimou, A.; Hong, Y.T.; Jäger, H.R.; Fox, Z.; Aigbirhio, F.I.; Fryer, T.D.; Menon, D.K.; Warburton, E.A.; Werring, D.J.; Baron, J.C. White Matter Perivascular Spaces on Magnetic Resonance Imaging: Marker of Cerebrovascular Burden? Stroke 2015, 46, 1707-1709. [CrossRef]

101. van Veluw, S.J.; Biessels, G.J.; Bouvy, W.H.; Spliet, W.G.; Zwanenburg, J.J.; Luijten, P.R.; Macklin, E.A.; Rozemuller, A.J.; Gurol, M.E.; Greenberg, S.M.; et al. Cerebral amyloid angiopathy severity is linked to dilation of juxtacortical perivascular spaces. J. Cereb. Blood Flow Metab. 2016, 36, 576-580. [CrossRef]

102. Nicoll, J.A.; Wilkinson, D.; Holmes, C.; Steart, P.; Markham, H.; Weller, R.O. Neuropathology of human Alzheimer disease after immunization with amyloid-Beta peptide: A case report. Nat. Med. 2003, 9, 448-452. [CrossRef] [PubMed]

103. Nicoll, J.A.R.; Buckland, G.R.; Harrison, C.H.; Page, A.; Harris, S.; Love, S.; Neal, J.W.; Holmes, C.; Boche, D. Persistent neuropathological effects 14 years following amyloid- $\beta$ immunization in Alzheimer's disease. Brain 2019, 142, 2113-2126. [CrossRef] [PubMed]

104. Boche, D.; Zotova, E.; Weller, R.O.; Love, S.; Neal, J.W.; Pickering, R.M.; Wilkinson, D.; Holmes, C.; Nicoll, J.A. Consequence of Abeta immunization on the vasculature of human Alzheimer's disease brain. Brain 2008, 131, 3299-3310. [CrossRef] [PubMed]

105. Gravina, S.A.; Ho, L.; Eckman, C.B.; Long, K.E.; Otvos, L., Jr.; Younkin, L.H.; Suzuki, N.; Younkin, S.G. Amyloid beta protein (A beta) in Alzheimer's disease brain. Biochemical and immunocytochemical analysis with antibodies specific for forms ending at A beta 40 or A beta 42 (43). J. Biol. Chem. 1995, 270, 7013-7016. [CrossRef]

106. Rinne, J.O.; Brooks, D.J.; Rossor, M.N.; Fox, N.C.; Bullock, R.; Klunk, W.E.; Mathis, C.A.; Blennow, K.; Barakos, J.; Okello, A.A.; et al. 11C-PiB PET assessment of change in fibrillar amyloid-Beta load in patients with Alzheimer's disease treated with bapineuzumab: A phase 2, double-Blind, placebo-Controlled, ascending-Dose study. Lancet Neurol. 2010, 9, 363-372. [CrossRef]

107. Liu, E.; Schmidt, M.E.; Margolin, R.; Sperling, R.; Koeppe, R.; Mason, N.S.; Klunk, W.E.; Mathis, C.A.; Salloway, S.; Fox, N.C.; et al. Bapineuzumab 301 and 302 Clinical Trial Investigators. Amyloid- $\beta$ 11C-PiB-PET imaging results from 2 randomized bapineuzumab phase 3 AD trials. Neurology 2015, 85, 692-700. [CrossRef]

108. Salloway, S.; Sperling, R.; Fox, N.C.; Blennow, K.; Klunk, W.; Raskind, M.; Sabbagh, M.; Honig, L.S.; Porsteinsson, A.P.; Ferris, S.; et al. Bapineuzumab 301 and 302 Clinical Trial Investigators. Two phase 3 trials of bapineuzumab in mild-To-Moderate Alzheimer's disease. N. Engl. J. Med. 2014, 370, 322-333. [CrossRef] 
109. Chantran, Y.; Capron, J.; Alamowitch, S.; Aucouturier, P. Anti-A $\beta$ Antibodies and Cerebral Amyloid Angiopathy Complications. Front. Immunol. 2019, 10, 1534. [CrossRef]

110. Bales, K.R.; O’Neill, S.M.; Pozdnyakov, N.; Pan, F.; Caouette, D.; Pi, Y.; Wood, K.M.; Volfson, D.; Cirrito, J.R.; Han, B.H.; et al. Passive immunotherapy targeting amyloid- $\beta$ reduces cerebral amyloid angiopathy and improves vascular reactivity. Brain 2016, 139, 563-577. [CrossRef]

111. Leurent, C.; Goodman, J.A.; Zhang, Y.; He, P.; Polimeni, J.R.; Gurol, M.E.; Lindsay, M.; Frattura, L.; Sohur, U.S.; Viswanathan, A.; et al. Immunotherapy with ponezumab for probable cerebral amyloid angiopathy. Ann. Clin. Transl. Neurol. 2019, 6, 795-806. [CrossRef]

112. Landen, J.W.; Andreasen, N.; Cronenberger, C.L.; Schwartz, P.F.; Börjesson-Hanson, A.; Östlund, H.; Sattler, C.A.; Binneman, B.; Bednar, M.M. Ponezumab in mild-To-Moderate Alzheimer's disease: Randomized phase II PET-PIB study. Alzheimers Dement. (N. Y). 2017, 3, 393-401. [CrossRef] [PubMed]

113. Ghosh, A.K.; Osswald, H.L. BACE1 ( $\beta$-secretase) inhibitors for the treatment of Alzheimer's disease. Chem. Soc. Rev. 2014, 43, 6765-6813. [CrossRef] [PubMed]

114. Cheng, X.; He, P.; Yao, H.; Dong, Q.; Li, R.; Shen, Y. Occludin deficiency with BACE1 elevation in cerebral amyloid angiopathy. Neurology 2014, 82, 1707-1715. [CrossRef] [PubMed]

115. Neumann, U.; Rueeger, H.; Machauer, R.; Veenstra, S.J.; Lueoend, R.M.; Tintelnot-Blomley, M.; Laue, G.; Beltz, K.; Vogg, B.; Schmid, P.; et al. A novel BACE inhibitor NB-360 shows a superior pharmacological profile and robust reduction of amyloid- $\beta$ and neuroinflammation in APP transgenic mice. Mol. Neurodegener. 2015, 10, 44. [CrossRef]

116. Meier, S.R.; Syvänen, S.; Hultqvist, G.; Fang, X.T.; Roshanbin, S.; Lannfelt, L.; Neumann, U.; Sehlin, D. Antibody-Based In Vivo PET Imaging Detects Amyloid- $\beta$ Reduction in Alzheimer Transgenic Mice After BACE-1 Inhibition. J. Nucl. Med. 2018, 59, 1885-1891. [CrossRef]

117. Schelle, J.; Wegenast-Braun, B.M.; Fritschi, S.K.; Kaeser, S.A.; Jährling, N.; Eicke, D.; Skodras, A.; Beschorner, N.; Obermueller, U.; Häsler, L.M.; et al. Early A $\beta$ reduction prevents progression of cerebral amyloid angiopathy. Ann. Neurol. 2019, 86, 561-571. [CrossRef]

118. Herzig, M.C.; Paganetti, P.; Staufenbiel, M.; Jucker, M. BACE1 and mutated presenilin-1 differently modulate Abeta40 and Abeta42 levels and cerebral amyloidosis in APPDutch transgenic mice. Neurodegener. Dis. 2007, 4, 127-135. [CrossRef]

119. Beckmann, N.; Doelemeyer, A.; Zurbruegg, S.; Bigot, K.; Theil, D.; Frieauff, W.; Kolly, C.; Moulin, P.; Neddermann, D.; Kreutzer, R.; et al. Longitudinal noninvasive magnetic resonance imaging of brain microhemorrhages in BACE inhibitor-treated APP transgenic mice. Neurobiol. Aging 2016, 45, 50-60. [CrossRef]

120. Imbimbo, B.P.; Watling, M. Investigational BACE inhibitors for the treatment of Alzheimer's disease. Expert. Opin. Investig. Drugs 2019, 28, 967-975. [CrossRef] 